\title{
Editorial ERA Forum 3/2021: EU strategy for a more effective fight against child sexual abuse
}

\section{Laviero Buono ${ }^{1}$}

Published online: 22 October 2020

(C) The Author(s) 2020

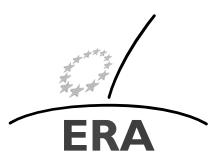

EUROPÄISCHE RECHTSAKADEMIE ACADEMY OF EUROPEAN LAW ACADEMIE DE DROIT EUROPEEN ACCADEMIA DI DIRITTO EUROPEO TRIER - TREVES - TREVIRI

For more than a decade, the European Union (EU) has made consistent efforts to develop a comprehensive legal framework to address the challenge of child sex abuse. Crimes of this nature are particularly severe in that they cause long-term physical and psychological harm to victims who, by their very nature, are particularly vulnerable.

The main piece of legislation addressing this issue was adopted in the mid-2000s and consisted of the 2004 EU Framework Decision on combating the sexual exploitation of children and child pornography. ${ }^{1}$ The main aim of this measure was to establish minimum rules concerning the definition of criminal offences and sanctions in this area of law.

However, due to the profound changes brought about by information and communication technologies (ICTs), within a few years of its adoption, the 2004 legal instrument was already the subject of intensive discussion between EU Member States. The use of information and communication technologies gave online predators a wide range of options for committing serious violations of the rights of the children. Hidden behind an allegedly "anonymity", offenders from all over the world could access children anywhere, anytime. This gave birth to new forms of phenomena such as on-

\footnotetext{
${ }^{1}$ Council Framework Decision 2004/68/JHA on combating the sexual exploitation of children and child pornography (OJ L 13, 20.1.2004).
}

L. Buono

LBuono@era.int

1 Head of Section - Criminal Law, Academy of European Law, Trier, Germany 
line sexual coercion and extortion ${ }^{2}$ and live-streaming of child sexual abuse, events which were once "emerging" trends, but today are "established" threats.

In consequence, in 2011, a new EU Directive was adopted. ${ }^{3}$ The Directive follows a holistic approach, encompassing provisions addressing the investigation and prosecution of offences, assistance to and protection of victims and the prevention of such crimes. Among the most important new features of the EU Directive there are the overall increase of penalties (which can now range from one to ten years in prison), the criminalisation of "grooming" (i.e., the solicitation of children on the internet for sexual purposes) and the introduction of new measures against websites containing or disseminating child pornography, mainly consisting in prompt removal at source and (voluntary) blocking by EU Member States. All in all, the new Directive substantially improves EU rules by addressing new forms of abuse and exploitation of children using information technology, meeting specific needs of child victims and introducing adequate measures to prevent offences. After its adoption in 2011, EU Member States had two years to bring into force the laws, regulations and administrative provisions necessary to comply with the Directive (the "transposition" phase).

On 16 December 2016, two reports of the EU Commission assessed the extent to which the EU Member States had taken the necessary measures in order to comply with the Directive. ${ }^{4,5}$ The reports stressed that an "integrated and holistic approach" was needed. It revealed that while much effort was being made to investigate and prosecute child sex abuse crimes, not enough attention was paid to preventing them. ${ }^{6}$ The analysis suggested that one of the main challenges for Member States related to prevention and intervention programmes.

In its 2016 Report, the European Commission acknowledged the significant efforts made by the Member States in the transposition of Article 25 of the Directive, however it noted that "there is still room to use its potential to the full by continuing to work on its complete and correct implementation across Member States".7

Finally, on 24 July 2020, the European Commission adopted an EU strategy for a more effective fight against child sexual abuse. ${ }^{8}$ The strategy presented a frame-

\footnotetext{
${ }^{2}$ See the 2017 Europol' report Online sexual coercion and extortion as a form of crime affecting children: law enforcement perspective, available here: https://www.europol.europa.eu/publications-documents/ online-sexual-coercion-and-extortion-form-of-crime-affecting-children-law-enforcement-perspective.

${ }^{3}$ Directive 2011/92/EU of the European Parliament and of the Council of 13 December 2011 on combating the sexual abuse and sexual exploitation of children and child pornography, replacing Council Framework Decision 2004/68/JHA (OJ L 335/1 of 17.12.2011).

${ }^{4}$ Report from the Commission to the European Parliament and the Council assessing the extent to which the Member States have taken the necessary measures in order to comply with Directive 2011/93/EU of 13 December 2011 on combating the sexual abuse and sexual exploitation of children and child pornography (COM(2016) 871 final).

${ }^{5}$ Report from the Commission to the European Parliament and the Council assessing the implementation of the measures referred to in Article 25 of Directive 2011/93/EU of 13 December 2011 on combating the sexual abuse and sexual exploitation of children and child pornography (COM(2016) 872 final).

${ }^{6}(\mathrm{COM}(2016) 871$ final, p. 20).

${ }^{7}$ (COM(2016) 872 final p. 12).

${ }^{8}$ Communication from the European Parliament, the Council, the European Economic and Social Committee and the Committee of the Regions - EU strategy for a more effective fight against child sexual abuse (Brussels, 24.07.2020, COM(2020) 607 final).
} 
work for EU action for the period 2020-2025 to respond in a comprehensive way to the increasing threat of child sexual abuse, both in its online and offline form. Eight concrete initiatives were announced to make use of all tools available at EU level, both legislative and non-legislative, covering prevention, law enforcement, and assistance to victims. Among the key actions were the creation of a European centre to prevent and counter child sexual abuse. Such a centre would bring together all the initiatives in this strategy by enabling more effective cooperation between public authorities (including law enforcement authorities), industry and civil society in the EU and globally, and by becoming the reference entity in the EU for expertise in this area.

In response to these needs, in 2019, the Academy of European Law - ERA, submitted an EU Project, which eventually received a grant under the Internal Security Fund - Police Programme 2014-2020 of the European Union.

The main objective of this Project is to offer practice-oriented training on methodologies and tools to prevent child sexual abuse online. It is structured around six training events organised throughout Europe over twenty-two months (May 2020 May 2022). Each event will last 1.5 days. The target groups of the Action are EU law enforcers, judges, prosecutors, academics, ministry officials and representatives of the civil society.

Each of these six seminars is targeted at different groups of selected Member States (circa 4-5 Member States per seminar, circa 50 participants per seminar) which are, to the extent possible, geographically close to each other (thus involving a "regional approach"), given that the need for cross-border cooperation is particularly important. The decentralised series of events guarantees a good geographical mixture among EU participants as well as networking opportunities which will encourage close contacts and cooperation among different professions.

In order to guarantee valuable practical training on preventing online child sex abuse material, the topics are dealt with by means of concrete case studies and demonstrations. National experts analyse the topics and present case studies based both on the individual national penal system and on the EU legislation in place. In this way, participants benefit from training that is tailor-made to deal with the questions and problems arising in their daily practice when dealing with cases involving online child sex abuse material.

In order to benefit from different perspectives, the groups of experts conducting the seminars consist of judges, prosecutors, academics, ministry officials and NGO representatives with experience in fighting online child abuse material. All in all, the Project guarantees that the seminars will effectively train 300 different EU legal practitioners.

In all the training events that are foreseen, the key challenges ahead related to preventing measures are presented and debated - i.e., ensuring that child sexual abuse material in Member States' territory is removed promptly; and that adequate safeguards are provided where a Member State opts to take measures to block access to internet users within its territory to web pages containing child sexual abuse material, etc.

To know more about this Project and register for one of the events, please have a look at the ad hoc website: https://preventing-csam.european.law/. 
Funding Note Open Access funding enabled and organized by Projekt DEAL.

Publisher's Note Springer Nature remains neutral with regard to jurisdictional claims in published maps and institutional affiliations.

Open Access This article is licensed under a Creative Commons Attribution 4.0 International License, which permits use, sharing, adaptation, distribution and reproduction in any medium or format, as long as you give appropriate credit to the original author(s) and the source, provide a link to the Creative Commons licence, and indicate if changes were made. The images or other third party material in this article are included in the article's Creative Commons licence, unless indicated otherwise in a credit line to the material. If material is not included in the article's Creative Commons licence and your intended use is not permitted by statutory regulation or exceeds the permitted use, you will need to obtain permission directly from the copyright holder. To view a copy of this licence, visit http://creativecommons.org/licenses/by/4.0/. 